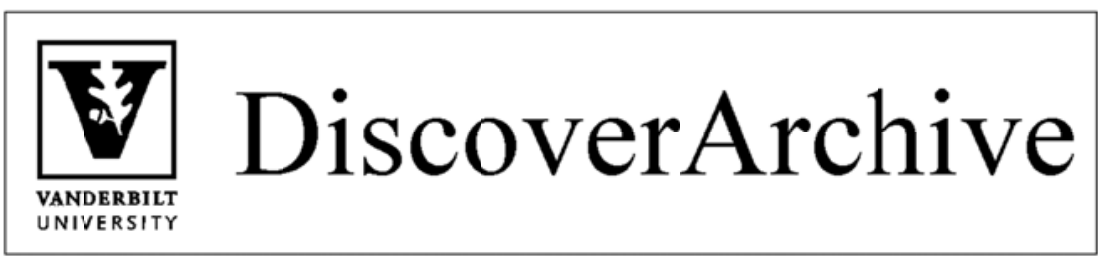

Retrieved from DiscoverArchive,

Vanderbilt University’s Institutional Repository

This work was originally published as Erin O'Connor, Economics, Public Choice, and the Perennial Conflict of Laws, in 90 Georgetown Law Journal 9412002. 


\section{HEINONLINE}

Citation: 90 Geo. L.J. 941 2001-2002

Content downloaded/printed from

HeinOnline (http://heinonline.org)

Wed Oct 10 12:02:47 2012

-- Your use of this HeinOnline PDF indicates your acceptance of HeinOnline's Terms and Conditions of the license agreement available at http://heinonline.org/HOL/License

-- The search text of this PDF is generated from uncorrected OCR text.

-- To obtain permission to use this article beyond the scope of your HeinOnline license, please use:

https://www.copyright.com/ccc/basicSearch.do?

\&operation $=$ go\&search Type $=0$

\&lastSearch $=$ simple\&all=on\&titleOrStdNo=0016-8092 


\title{
Economics, Public Choice, and the Perennial Conflict of Laws
}

\author{
ERIN ANN O'HARA*
}

\section{INTRODUCTION}

Thumbs up to Andrew Guzman ${ }^{1}$ for joining the growing rank of scholars who have identified the utility of economic reasoning in resolving the conflict-oflaws dilemma. ${ }^{2} \mathrm{~A}$ few others have identified the importance of focusing on individual interests ${ }^{3}$ and of resolving conflicts in some way that optimizes the aggregate utility of those individuals as well as the societies that are affected. ${ }^{4}$ Others have pointed out that an efficiency analysis must take into account the effect of conflicts policies on substantive laws. ${ }^{5}$ And, a handful of scholars have begun to consider how the implications of public choice theory affect both positive and normative economic analyses of the conflicts problem. ${ }^{6}$ Guzman

* Professor of Law, Vanderbilt University. I received research support for this project from the Dean's Fund at Vanderbilt Law School.

1. Andrew Guzman, Choice of Law: New Foundations, 90 Geo. L.J. 883 (2002).

2. In addition to those authors cited by Paul B. Stephan in The Political Economy of Choice of Law, 90 GEo. L.J. 957, 957 n.2 (2002), economic analyses are incorporated into LEA BRILMAYER, CoNFLICT OF Laws (2d ed. 1995); Richard A. Posner, Economic Analysis of Law 587-88 (5th ed. 1998); Michael J. Whincop, Mary Keyes \& Richard A. Posner, Policy and Pragmatism in the Conflict of Laws (2001); 1 The New Palgrave Dictionary of Economics and the Law 241, 395 (Peter K. Newman ed., 1998); William F. Baxter, Choice of Law and the Federal System, 16 Stan. L. Rev. 1 (1963); Patrick J. Borchers, The Choice-of-Law Revolution: An Empirical Study, 49 WASH. \& LEE L. REv. 357 (1992); Bruce L. Hay, Conficts of Law and State Competition in the Product Liability System, 80 Geo. L.J. 617 (1992); Bruce H. Kobayashi \& Larry E. Ribstein, Contract and Jurisdictional Freedom, in THE FALL ANd Rise of Freedom of Contract 325 (F.H. Buckley, ed. 1999); Larry Kramer, Rethinking Choice of Law, 90 Colum. L. Rev. 277 (1990); Michael E. Solimine, An Economic and Empirical Analysis of Choice of Law, 24 GA. L. REv. 49 (1989); Stuart E. Thiel, Choice of Law and the Home-Court Advantage: Evidence, 2 AMER. L. \& ECON. Rev. 291 (2000); and Joel P. Trachtman, Economic Analysis of Prescriptive Jurisdiction and Choice of Law, 42 VA. J. INT'L. LAW 1 (2001). My own articles on the law and economics of conflicts include William H. Allen \& Erin A. O'Hara, Second Generation Law and Economics of Conflict of Laws: Baxter's Comparative Impairment and Beyond, 51 STAN. L. REv. 1011 (1999); Erin Ann O'Hara \& Larry E. Ribstein, Conflict of Laws and Choice of Law, in 5 ENCYCLOPEDIA of LAW AND ECONOMICs 631, 653-60 (Boudewijn Bouckaert \& Gerrit De Geest eds. 2000); Erin A. O'Hara \& Larry E. Ribstein, From Politics to Efficiency in Choice of Law, 67 U. CHI. L. REv. 1151 (2000) [hereinafter O'Hara, From Politics to Efficiency]; Erin O'Hara \& Larry E. Ribstein, Interest Groups, Contracts and Interest Analysis, 48 MERCER L. REv. 765 (1997) [hereinafter O'Hara, Interest Groups]; and Erin Ann O'Hara, Opting Out of Regulation: A Public Choice Analysis of Contractual Choice of Law, 53 VAND. L. REv. 1551 (2000).

3. WhinCOP \& KeYES, supra note 2; O'Hara \& Ribstein, From Politics to Efficiency, supra note 2; Paul B. Stephan, Regulatory Cooperation and Competition: The Search for Virtue, in TRANSATLANTIC Regulatory Cooperation-Legal Problems and Political Prospects 167 (George A. Bermann, et al. eds., 2000).

4. Baxter, supra note 2.

5. See Hay, supra note 2; O'Hara \& Ribstein, From Politics to Efficiency, supra note 2; O'Hara \& Ribstein, Interest Groups, supra note 2; Stephan, supra note 3.

6. See O'Hara, supra note 2; O'Hara \& Ribstein, From Politics to Efficiency, supra note 2; O'Hara \& Ribstein, Interest Groups, supra note 2; Stephan, supra note 3. Some conflicts scholars have 
seems very much on board with these important developments, and he brings to the table original and sophisticated analysis.

Guzman's article forces one to think more carefully about efficiency approaches to choice of law and the normative implications of the analysis. Critically evaluating the work of similarly inclined colleagues can be quite valuable because it forces the evaluator away from the podium and into the audience. As a listener rather than producer of economic analyses of conflict of laws, some of the challenges of the efficiency approach to conflicts become more apparent. This response addresses two types of difficulties with which all economic analyses of conflict of laws must contend. Both stem from the incorporation of public choice theory into the efficiency analysis. First, public choice theory confounds our attempts to draw normative conclusions about efficient choice-of-law policies, and second, public choice theory exposes the likely futility of attempting to resolve conflicts in an efficient manner. ${ }^{7}$

\section{Public Choice and Normative Analyses of Conflict of Laws}

Although in principle an efficiency approach to choice of law seems simple, the devil, as always, lurks in the details. Obviously, we strive to maximize aggregate welfare, but the problem becomes much more difficult once we attempt to ascertain the effects of competing choices of law. Paul Stephan has already pointed out the inherent manipulability of an effects test. ${ }^{8}$ If we add to that the difficulty of allocating effects in a dynamic model that accounts for resulting changes in substantive laws, then efficiently resolving every conflicts issue becomes depressingly daunting. For that reason, choice of law might appropriately lean toward rules designed more or less to get the problem right most of the time-a point that Guzman seems to acknowledge. ${ }^{9}$

Unfortunately, the addition of public choice confounds the efficiency analysis even further, because it calls into question even those conflicts rules that appear to be Pareto superior. ${ }^{10}$ Guzman focuses on the hard task of finding efficient

analyzed choice of law from a game theoretic perspective. See BRILMAYER, supra note 2, at 169-218; Kramer, supra note 2, at 339-44.

7. Although this response covers slightly different territory than does Stephan, supra note 2, I fundamentally agree with his public choice critique of Guzman's article. I step back to offer some views on the difficulties that public choice theory poses for all who strive for the optimal resolution of conflict of laws.

8. Id. at 964 ("As open-ended standards go, the effects test is especially deficient in the precision department. It requires only a causation story to apply, limited solely by the creativity of the storyteller.").

9. See Guzman, supra note 1, at 992-93 (arguing that location of transaction rule may be acceptable proxy for effects because, although imperfect, it avoids costs and uncertainty).

10. Pareto-superior situations are those that make at least one person better off while leaving no one worse off. Posner, supra note 2, at 14. The enforcement of choice-of-law clauses promotes Paretosuperior transactions. A conflicts rule that provides for the enforcement of choice-of-law clauses may be Pareto optimal if no other conflicts treatment could be adopted without making at least one person worse off. I question here whether, once we look beyond the transaction, enforcement of choice-of-law clauses actually makes everyone better off and no one worse off. 
solutions where the choice of law will benefit some individuals and states to the detriment of the interests of other individuals and states. I focus here on the narrow, assumedly safe, haven for economists-contractual choice of law. Although contractual choice of law might appear to enhance Pareto efficiency, the enforcement of these contract clauses can increase the existence of substantive laws that transfer wealth from one contracting party to another. If Paretosuperior contract provisions can lead to Pareto-inferior substantive laws, the efficiency of choice-of-law rules enforcing choice-of-law clauses is called into question. Section A briefly describes the conventional efficiency analysis to which Guzman subscribes, while Section B illustrates how public choice theory confounds the analysis. Section $c$ describes one tradeoff that choice-of-law policymakers need to consider before definitively concluding that one approach is more efficient than another.

\section{A. IS CONTRACTUAL CHOICE OF LAW PARETO OPTIMAL?}

Guzman's assertion that many choice-of-law clauses should be enforced seems uncontroversial because it is so intuitively appealing. ${ }^{11}$ Where there are no third-party effects, or externalities, the parties should be permitted to choose the law that governs their relationship. ${ }^{12}$ There are several reasons for this. First, contractual relationships are, after all, heterogeneous in nature, and the one-sizefits-all contract law of a single state may not work as well for the parties as an alternative bundle of contract law. ${ }^{13}$ Second, some states have developed a sophisticated body of law to govern specialized relationships: Domestic examples include New York's commercial law, Delaware's corporate law, and Connecticut's insurance law. ${ }^{14}$ These states provide a public good to the contracting parties, and it follows that the public good becomes even more valuable if it can be enjoyed by out-of-state as well as domestic parties. Allowing foreign parties to take advantage of these laws appears to increase global welfare unambiguously, at least where the relationship does not affect the welfare of individuals outside the contract. Third, contractual choice of law promises to foster jurisdictional competition between states for the best bundle of contract laws, at least to the extent that legislators and judges respond to the widespread choice of foreign law. ${ }^{15}$

11. See Guzman, supra note 1, at 913-15.

12. Id. at 50 .

13. See Stephen J. Choi \& Andrew T. Guzman, Portable Reciprocity: Rethinking the International Reach of Securities Regulation, 71 S. CAL. L. REV. 903, 916-17 (1998) (stating that issuers and investors are diverse, and choice of securities laws enables parties to gravitate toward most appealing laws).

14. See O'Hara \& Ribstein, From Politics to Efficiency, supra note 2, at 1224 ("[W] specializes in the formulation of valuable regulation, as for example with Delaware corporate law and Connecticut insurance law, party choice enhances the value of that asset.").

15. Choi \& Guzman, supra note 13, at 916-24; O'Hara \& Ribstein, From Politics to Efficiency, supra note 2, at 1161-63; Roberta Romano, Empowering Investors: A Market Approach to Securities Regulation, 107 YALE L.J. 2359, 2427 (1998); Stephan, supra note 3, at 168. 
Precisely because the Pareto analysis requires the absence of third-party effects, those opposed to party choice are quick to argue either that one party to the transaction has not really consented to the choice (creating a third-party effect in Guzman's terminology), ${ }^{16}$ or that individuals outside the contract might be affected by the choice of governing law. ${ }^{17}$ I agree with Guzman that many contracts, including those that implicate securities and bankruptcy law, ${ }^{18}$ tend to involve only negligible third-party problems, so I will instead focus here on a less obvious difficulty with the enforcement of choice-of-law clauses. Even assuming the absence of third-party effects, enforcing these provisions can be suboptimal because the ability to opt out of inefficient laws makes the existence of these laws more probable. ${ }^{19}$ Efficiency analysis, thus, requires that the enhanced welfare of the parties be weighed against the social costs of suboptimal legislation.

\section{B. THE FRANCHISE CONTRACT EXAMPLE}

Franchise contracts provide a useful example. ${ }^{20} \mathrm{~A}$ company that provides retail goods and services must worry about the tendency of store managers to shirk rather than earn profits for the company. The salaried manager of a Burger King or a Dunkin' Donuts has little incentive to manage the store properly, especially if the company has difficulty identifying the causes of lowered profits. ${ }^{21}$ In contrast, effective managers internalize the profit-seeking objectives of the company, and the company can better align the store managers' incentives with its own by establishing franchise outlets. ${ }^{22}$ By doing so, the franchi-

16. See sources cited in Guzman, supra note 1, at 913-14 and accompanying text; see also William J. Woodward, Contractual Choice of Law: Legislative Choice in an Era of Party Autonomy, 54 SMU L. REv. 697, 740-45 (2001) (arguing that party autonomy model of contractual choice of law does not apply to consumer contracts).

17. See Guzman, supra note 1, at 915 (noting that tort plaintiffs are usually third-party creditors who have no notice of firm's choice of bankruptcy regime).

18. Others have advocated that firms have a choice regarding their bankruptcy and securities regimes. See Robert K. Rasmussen, A New Approach to Transnational Insolvencies, 19 MiCH. J. INT'L L. 1, 5-6 (1997) (bankruptcy law); Romano, supra note 15, at 2427 (securities law).

19. Although I have discussed this general issue elsewhere, O'Hara, supra note 2, I invoke a similar analysis again here to illustrate the difficulty that public choice theory poses for efficiency analysis.

20. Throughout this section, the term "franchise" is used to refer to business-format franchising, as opposed to product and trademark franchising. The former type is more inclusive, and is "characterized by an ongoing business relationship between franchisor and franchisee that includes not only the product, service and trademark, but the entire business format itself-a marketing strategy and plan, operating manuals and standards, quality control, and continuing two-way communications." U.S. Dep't of Commerce, Franchising in the ECONOMY 1985-87, at 3 (1987).

21. On the inferior incentives of managers who do not capture all of the residual claims of a firm, see Michael C. Jensen \& William H. Meckling, Theory of the Firm: Managerial Behavior, Agency Costs and Ownership Structure, 3 J. Fin. Econ. 305, 312-23 (1976).

22. See D.L. Noren, The Economics of the Golden Arches: A Case Study of the McDonald's System, 34 Ам. ECONOMIST 60, 62 (1990) (noting that McDonald's franchised in order to avoid the poor entrepreneurial incentives of company-run stores). In fact, companies tend to franchise those units that are located far from company headquarters and in rural areas. See James A. Brickley \& Frederick H. Dark, The Choice of Organizational Form, 18 J. FIN. ECON. 401, 411-19 (1987). These units may be the hardest to monitor and most likely to attract repeat business. See id. 
see becomes the residual claimant of store profits, and she loses her investment if the store fails. ${ }^{23}$ She enjoys the brand name consumer appeal of the company's trademark, and in return she must agree to comply with fairly detailed specifications about how that business must be operated. Franchise agreements can be quite detailed, specifying the prices charged, items offered, operating hours, service procedures, ingredients, materials, uniforms, and much more. ${ }^{24}$ These details help the franchisor retain and enhance the value of the company's trademark, ${ }^{25}$ which is the ultimate source of its profits.

To help ensure performance by franchisees, the franchise contracts often enable the franchisors to terminate the contracts without cause and without notice ${ }^{26}$ Although seemingly draconian, defenders of franchise contracts argue that these provisions are necessary to prevent individual franchisees from free-riding off the value of the trademark. ${ }^{27}$ When a franchise is located along a highway or in a large tourist area, many of its customers will not expect to return. The Burger King franchisee may have little incentive to painstakingly preserve the reputation of Burger King because she gets the benefits of Burger King's reputation regardless of her behavior, so long as other franchisees preserve the trademark's value. ${ }^{28}$ Nonrepeat customers will come to her store in either event, and it is much more profitable for her, individually, to reduce the quality of the service or food provided. ${ }^{29}$ The only way to ensure that she complies with her obligations is to enable the franchisor to threaten immediate termination. These contract provisions can enhance the value of the franchisor's contracts because both franchisor and franchisees as a group benefit from the preservation of the value of the trademark.

Franchisor termination rights thus help prevent franchisee opportunism, but only by creating an opportunity for franchisor opportunism. ${ }^{30}$ The unscrupulous franchisor can choose to take over the most profitable franchises after the franchisee's initial investments have been sunk into the facility. ${ }^{31}$ Of course, this

23. For a description of the initial capital requirements and other costs incurred by franchises, see Gillian K. Hadfield, Problematic Relations: Franchising and the Law of Incomplete Contracts, 42 STAN. L. Rev. 927, 934-36 (1990).

24. See id. at $933 \&$ n. 29.

25. See O'Hara, supra note 2, at 1590.

26. See Benjamin Klein, The Economics of Franchise Contracts, 2 J. CoRP. FIN. 9, 18 (1995) ("It is the threat of termination, rather than the use of the court to enforce the written terms of the contract alone, that produces the incentive on the part of the franchisee to perform.").

27. See Benjamin Klein, Transaction Cost Determinants of "Unfair" Contractual Arrangements, 70 Am. Econ. Rev. 356, 358-60 (1980) (Papers and Proceedings of the Ninety-Second Annual Meeting of the American Economic Association).

28. See J. Howard Beales III \& Timothy J. Muris, The Foundations of Franchise Regulation: Issues and Evidence, 2 J. CoRP. FIN. 157, 159 (1995) (describing franchisees' incentives to free-ride off trademark value).

29. See Kobayashi \& Ribstein, supra note 2, at 340 ("Absent a mechanism to control shirking and free-riding, a franchisee that largely serves nonrepeat customers has an incentive to reduce quality below that desired by the franchisor.").

30. See Hadfield, supra note 23, at 951-53.

31. See id. 
behavior can reduce the franchisor's ability to attract franchisees, so reputational concerns help deter franchisor opportunism. ${ }^{32}$ Nevertheless, local franchisees have been successful in convincing several state legislatures of the need for franchise protection statutes. ${ }^{33}$ These statutes vary in their terms, but most, at a minimum, eliminate the franchisor's ability to terminate franchise contracts without showing cause ${ }^{34}$ and provide some opportunity for the franchisee to cure the defects in her performance. ${ }^{35}$

To illustrate my point, I must insert a simplifying assumption about the efficiency of these statutes. Supporters and opponents of franchise protection statutes essentially disagree about whether franchisor or franchisee opportunism is more costly. In addition to the costs that are imposed on the parties themselves, opponents of the statutes claim that by reducing the franchisor's ability to monitor franchisee performance effectively, there is a dead weight efficiency loss that is, in part, borne by consumers. ${ }^{36}$ Although I acknowledge these complications, I ignore them for purposes of explicating a separate problem. I will assume here that the franchise protection statutes are inefficient, although I will ignore any third-party effects of the statutes.

So viewed, the franchise protection statutes transfer wealth from franchisor to franchisee because they enable individual franchisees some latitude to free ride off the company trademark and thereby earn greater profits. The company earns smaller profits with free riding because the value of its trademark is affected. Of course, the franchisee's benefit is short term because presumably franchisors will take back the transfers in future contracts by raising the price of the franchise or the price of franchisor-controlled supplies. ${ }^{37}$ Because franchise agreements are long-term contracts, typically incorporating ten-to-twenty-year terms ${ }^{38}$ even a single-period transfer can be significantly valuable to existing franchisees. ${ }^{39}$

Whether these laws are ultimately worth pursuing depends upon the extent to which the benefits of these laws to the franchisees exceed any costs incurred.

32. See Beales \& Muris, supra note 28 , at 161 .

33. Sixteen states have franchise protection laws. See Kobayashi \& Ribstein, supra note 2, at 325 , $446 \mathrm{n} .106$ (listing regulating states).

34. All sixteen states' statutes require cause for termination. See id.

35. Ten states' statutes give a right to cure for defective performance. See id. at 340,446 n. 107 .

36. See id. at 340-41, $447 \mathrm{nn} .114-19$ (citing empirical studies supporting hypothesis that franchise termination laws are wealth-reducing).

37. To prevent the franchisor from simply deciding not to renew the contract, ten of the regulating states require cause for nonrenewal. See id. at $446 \mathrm{n} .106$ (listing the states).

38. In 1986, an estimated eighty percent of the contracts extended the franchise for a period between five and twenty years, and nearly sixty-five percent of the contracts included terms between ten and twenty years. See Hadfield, supra note 23, at 937 (citing U.S. DEP'T of COMMERCE, supra note 20, at 13).

39. Once the possibility of franchise regulation is raised, a franchisor may, in addition to raising the prices it charges franchisees, shorten the contract terms to limit the period before the transfer can be taken back. Presumably the longer term was valuable to the franchisee. 
Costs include the cost of organizing and lobbying for the laws, ${ }^{40}$ which depend on the ability of franchisors to organize opposition to proposed regulations. Even assuming that franchisors are able to capture the attention of the state legislature, their willingness to spend money to mount opposition turns on the costs they expect to incur with the enactment of a bill.

The costs to the franchisor include more than just the amount of the one-time wealth transfer, because if the law is inefficient, both parties suffer dead weight losses. In the new contracts, franchisees presumably pay higher prices for their franchises, and in return, they receive franchise protections. Unfortunately, however, the original contracts, with lower franchise prices and increased franchisor monitoring ability, will generate greater aggregate profits. The transfer from franchisor to franchisee may be temporary, but notice that the dead weight losses would be incurred throughout the life of the statute. Moreover, both parties incur a portion of the dead weight losses (in the form of reduced profits). Inefficient laws decrease the proponents' incentives to lobby for their passage while increasing the incentive of the opponents to fight against them. Thus, the more inefficient the law, the less likely it will be enacted. ${ }^{41}$

The preceding argument assumed that both parties would incur dead weight losses into the future. If instead the franchisees could find some way to avoid these losses, then they increase the likelihood that the franchisee protection statutes will be enacted. One possibility would be to precommit to lobbying for the repeal of the statute once the franchise contract periods expired. A repeal would enable the franchisees to obtain their wealth transfers while minimizing the future dead weight losses. However, repeal becomes problematic for two reasons. First, there is always a risk that the repeal would be unsuccessful, and even if successful, efforts to get the law repealed adds to the costs of franchise protection. Second, new contracts presumably will be drafted at different times, and those that have been redrafted will already have incorporated increased franchise prices. Franchisees with new contracts likely would oppose the repeal of the statute because the repeal would transfer wealth back to the franchisor. After all, these franchisees will have paid for franchise protections that they will not receive without the law.

Contractual choice of law provides a more promising mechanism for minimizing the dead weight losses of an inefficient law. ${ }^{42}$ Franchise protection affects a one-time transfer of wealth to existing franchisees, and franchisees reap the benefits of the transfer throughout the life of the preexisting contract. Future dead weight losses can be minimized in future contracts so long as the parties can include a choice-of-law clause. Parties can use the clause to opt out of the regulation by choosing the law of a nonregulating state. If effective, then the

40. See Gordon Tullock, The Welfare Costs of Tariffs, Monopolies, and Theft, 5 W. Econ. J. 224, 228 (1967) (emphasizing significant social costs incurred in private efforts to obtain favorable laws).

41. Cf. Gary S. Becker, A Theory of Competition Among Pressure Groups for Political Influence, 98 Q.J. ECoN. 371, 395 (1983) (arguing that increased dead weight costs of regulation discourage interest group proponents while encouraging taxpayer opposition).

42. See O'Hara, supra note 2, at 1598-99. 
future contracts can take the form of the more efficient, original contracts. The price of the franchise is lower than would be the case with franchise termination protection, and the franchisor is better able to monitor franchisee free riding off the franchise trademark. Most importantly, this increased efficiency of future contracts does not reverse the direction of the legislative wealth transfer from franchisor to franchisee. In other words, choice-of-law clauses increase the net benefits of wealth transfers to franchisees while decreasing the net costs to franchisors. By increasing the net benefit to franchisees, choice-of-law clauses give them more incentive to lobby for the franchise protection statute. At the same time, because choice-of-law clauses decrease the costs of termination protection to the franchisors, the franchisors have less incentive to oppose it. On balance then, the enforcement of choice-of-law clauses can increase the incidence of inefficient laws.

\section{THE TRADEOFFS}

Notice what has happened to choice-of-law clauses. Guzman states that in the absence of third-party effects, enforcing choice-of-law clauses will increase aggregate welfare. ${ }^{43}$ The statement made sense because presumably parties only incorporate a term into their contract if it increases the value of the contract. Because no one else suffers and at least one of the parties is better off, enforcing the clause effects a Pareto improvement. Once we step back and think about the issue in dynamic terms, we begin to think about how the substantive laws can be affected by the choice-of-law rule. The introduction of interest-group competition forces us to conclude that enforcing choice-of-law clauses may not always increase aggregate welfare. Without the clauses, the wealth transfer, its current dead weight losses, and the organizing and lobbying costs might be avoided. ${ }^{44}$

I do not mean to imply that choice-of-law clauses should be banned. There are many welfare-enhancing benefits to the enforcement of choice-of-law clauses, whereas the number of circumstances in which contracting parties can use the law to transfer wealth between them may be relatively small. ${ }^{45}$ Quite likely, a policy of enforcing choice-of-law clauses creates more wealth than it destroys. I merely point out that the introduction of public choice considerations raises questions about even the simplest of normative conclusions that can be drawn from welfare-enhancement models. We will all need to think more carefully about the political economy of choice of law.

\section{GetTing to EfFicienCy}

The field of conflict of laws has had difficulty keeping the attention of the best academic minds. A scholar with strong analytic abilities hopes to solve the

43. See Guzman, supra note 1, at 914-17.

44. The wealth transfer itself has no effect on aggregate welfare, but the other costs do.

45. For the mechanism described here to work, one party must be able to reap an advantage from the other during the existing contract period. At a minimum, long-term contracts are required. 
conflicts problem, but just as soon as that scholar begins to solve the matter on a normative level, he or she also begins to understand why the solution is unattainable as a positive matter. ${ }^{46}$ Baxter, Brilmayer, Kramer, and now Guzman, among others, have acknowledged the difficulty of getting states to improve choice of law, and each ultimately calls for some mechanism to encourage state cooperation.$^{47}$ No state has much incentive unilaterally to adopt sensible choice-of-law rules; rather, the problem can be resolved only by getting the states to coordinate their efforts. Cooperation among the states, however, is highly unlikely. ${ }^{48}$ States are unlikely to agree on any particular choice-of-law rule because they represent the interests of their constituents rather than an interest in global welfare. Any rule will disadvantage some states relative to the status quo, making it difficult to obtain across-the-board agreement. Guzman offers a sensible way to resolve the problem-logroll the issues in such a way that the states who lose under one rule still have an incentive to get on board in order to receive the benefits of other rules. ${ }^{49}$ Unfortunately, his solution will not likely work, at least not any time soon. Public choice theory helps to understand why.

\section{A. BARGAINING POWER AND ENFORCEMENT DIFFICULTIES}

Any effort to push states to agree on choice-of-law rules likely will be thwarted by the larger states. As the trend of rejection of the First Restatement within the United States suggests, larger states are systematically advantaged by using choice of law to enhance the welfare of their own residents, and the attractiveness of their markets indicates that they can get away with proresident, pro-forum law biases in their choice-of-law decisionmaking. ${ }^{50}$ Once the largest states fall off the wagon, the others have little incentive to continue to comply. The problem with interstate compacts is not that larger states prefer rules that smaller states dislike. Instead, the larger states prefer not to be confined by rules at all. These states prefer to further their own commercial and social interests case-by-case and the sheer magnitude of their markets gives them the ability to resist interstate choice-of-law compacts.

46. Stewart Sterk, for example, has taken the position that courts and states are simply uninterested in choice-of-law theory. See Stewart Sterk, The Marginal Relevance of Choice of Law Theory, 142 U. PA. L. Rev. 949, 951-52 (1994).

47. BRILMAYER, supra note 2, at 181-218 (identifying benefits from state cooperation and exploring possible means to achieve it); Baxter, supra note 2, at 22-42 (calling for federal courts to take the lead in their choice-of-law decisions in diversity cases by building a set of precedents that state courts may have an incentive to use); Kramer, supra note 2, at 319-44 (proposing canons of construction and suggesting that states can solve cooperation problems through iterative interactions).

48. Because of the difficulty of achieving state cooperation, I have elsewhere explored the possibility that states may eventually evolve toward efficient rules through the forces of competition rather than cooperation. See O'Hara \& Ribstein, From Politics to Efficiency, supra note 2, at 1227-31.

49. Guzman, supra note 1, at 904-06.

50. See Sterk, supra note 46 , at 1006 (pointing out that larger states have less incentive to cooperate with efforts to adopt modest choice-of-law rules (citing LEA BrILMAYER, Conflict of Laws: FoundaTIONS AND FUTURE DiRECTIONS 178-86 (1991))). 
Even if the largest states could be induced to sign on by attaching the conflicts agreement to a multilateral trade agreement, who would enforce it? Will the courts of one state read all the opinions of the courts of another state to make sure that they are complying? What happens if it appears that they are not? Monitoring difficulties can be ameliorated by the adoption of rules rather than standards in choice of law, but even then, our experience under the First Restatement indicates choice-of-law rules are inherently manipulable.

Compounding these monitoring difficulties is a dearth of incentive on the part of interest groups to help government pay attention to whether other countries are complying with choice-of-law agreements. When China fails to comply with its obligations under the GATT's Agreement on Trade-Related Aspects of Intellectual Property (TRIPs), powerful interest groups can mobilize the United States and other countries to take action. ${ }^{51}$ However, because choice of law is procedural, and therefore politically less salient, it will be difficult, if not impossible, to motivate groups to protest or otherwise act to help ensure enforcement. Most likely, the costs of noncompliance are simply too diffuse. In short, even clear, nonmanipulable rules may not ensure interstate cooperation in the context of choice of law.

\section{B. RULES AND STANDARDS}

Assuming arguendo that countries are willing to draft a choice-of-law agreement and are willing to comply with that agreement, will it take the form of rules or standards? Prior to the 1960s, choice of law within the United States took the form of rules. ${ }^{52}$ Tort claims, for example, were resolved according to the law of the place of the wrong, ${ }^{53}$ and property claims were resolved according to the law of the situs of the property. ${ }^{54}$ More recently, state courts have adopted multifactored, standard-based approaches to resolve these conflicts. ${ }^{55} \mathrm{I}$ have elsewhere taken the position that efficiency in choice of law requires rules. ${ }^{56}$ Rules, although subject to manipulation at times, increase certainty and predictability while decreasing forum shopping and judicial discretion. ${ }^{57}$ In

51. See Scott J. Palmer, Note, An Identity Crisis: Regime Legitimacy and the Politics of Intellectual Property Rights in China, 8 Ind. J. Global. Legal Stud. 449, 449 (2001) (noting continued U.S. pressure on China to enforce laws required by TRIPs). See generally RoBert G. SuTTER, U.S. PolicY Toward China: An INTROduction to THE Role of INTEREST Groups (1998) (describing the shaping of U.S. policies toward China by American interest groups).

52. See Restatement of Conflict of Laws (1934).

53. Id. $\$ 378$.

54. Id. $\$ 208$.

55. For an analysis of rules versus standards in choice of law, see 1 THE New Palgrave Dictionary of ECONOMICS AND THE LAW, supra note 2, at 389-95.

56. Allen \& O'Hara, supra note 2, at 1040-47; O'Hara \& Ribstein, From Politics to Efficiency, supra note 2, at 1153, 1187-90; O'Hara \& Ribstein, Interest Groups, supra note 2, at 765-66, 768-70.

57. Rules advocates include Maurice Rosenberg, The Comeback of Choice-of-Law Rules, 81 CoLUM. L. Rev. 946 (1981), and Willis L.M. Reese, Choice of Law: Rules or Approach, 57 CoRNEu L. REv. 315 (1972). For discussions of the benefits of rules from the law and economics perspective, see WHINCOP \& KEYES, supra note 2, at 24-31; 1 The New Palgrave Dictionary of Economics and the Law, supra note 2, at 395. 
many circumstances, poor choice-of-law rules are better than good choice-oflaw standards. Guzman appears unsure about whether rules or standards are better for choice of law, or perhaps he thinks that rules are better in some places while standards are better in others. This latter conclusion is bound to be correct, for I must admit that sophisticated economic analysis is likely to lead to the conclusion that a mix of rules and standards is optimal. I thank Guzman for challenging me to think more carefully about rules and standards, and I hope that his work focuses on this issue in the near future.

Assuming that we could all agree on the efficient form of the resolution of a conflicts issue, we must determine whether it is possible to reform choice of law to achieve that form. Unfortunately, a public-choice analysis of rules and standards indicates that, as a positive matter, the form of law chosen instead can reflect the balance of interest-group influence on the law-drafting body. In other words, whether the drafters of a choice-of-law compact choose to incorporate rules or standards likely turns on the number of opposing interests present when a particular issue is raised.

Alan Schwartz and Robert Scott have made this point in the context of private lawmaking bodies ${ }^{58}$ but surely the difficulty extends as well to the drafting of multilateral treaty agreements. If only one interest is represented in the drafting process, then the issue likely will be resolved by a rule, which will likely represent the interests of the present group. ${ }^{59}$ The idea is that the most preferred legal statement for an interest group is a rule that favors the group because it generates clear and certain benefits. ${ }^{60}$

Consider, for example, the issue of which state's law applies in a products liability suit. Manufacturers presumably would prefer to resolve the matter according to the law of the place of manufacture because it enables them to choose the law through the location of their plants. ${ }^{61}$ Plaintiffs' attorneys, on the other hand, might prefer to resolve these tort matters according to the law of the forum. ${ }^{62}$ If we alter the litigation context, then the preferences of the parties can

58. Alan Schwartz \& Robert E. Scott, The Political Economy of Private Legislatures, 143 U. PA. L. Rev. 595 (1995). In their article, private lawmaking bodies are nongovernment institutions that draft legal proposals for adoption by the states. Their primary examples include the American Law Institute (ALI), which drafts the Restatements, and the National Conference of Commissioners on Uniform State Laws (NCCUSL), which drafts uniform law proposals, and, in conjunction with the ALI, promulgates the Uniform Commercial Code provisions. Id. at 596-97, 600-02.

59. Schwartz and Scott argue that much of Article 9 of the Uniform Commercial Code reflects the fact that asset-based financers and banks constituted the only cohesive interest group that became involved in the drafting process. Id. at 638-42.

60. See id. at 651 (suggesting that precise rules result from a dominant interest group attempting to preserve its victory by constraining judicial or administrative discretion).

61. An even better solution for manufacturers might be enforcement of choice-of-law clauses in products liability cases. Because the manufacturer typically drafts the agreement, a clause might enable it to choose the governing law without actually moving its plant to the state with the preferred law. This solution requires that the manufacturer have the predominant influence over the choice of the governing law.

62. Because plaintiffs choose the forum in which to sue, a forum rule might be better than a domicile rule for plaintiffs who reside in manufacturer-friendly states. Moreover, determination of the domicile 
change. In the debtor-creditor context or the employment context, where it is less clear at the outset which party will be plaintiff and which defendant, the debtor and the employee probably prefer a domicile rule to a forum rule.

Two examples help to illustrate this latter point. The first involves current efforts to redraft the Uniform Commercial Code provision governing contractual choice of law. The current provision states that the parties can choose any law that is reasonably related to the parties or their transaction. ${ }^{63}$ The provision likely is both underinclusive and overinclusive in its permissiveness. It is underinclusive because the relationship requirement prevents sophisticated commercial parties from choosing unrelated law in order to take advantage of the expertise provided in New York's commercial law. At the same time, the current relationship rule is overinclusive because it does too little to protect consumer interests. A business that wants to avoid consumer protection laws simply locates in an unregulating state, includes a choice-of-law provision in the contract designating the law of the unregulating state, and the consumer protections are evaded. Consumers could advocate that courts apply the law of the forum state to determine whether the clause is enforceable. Unfortunately for them, however, the consumer does not always choose the forum. In the consumer contract context, consumers often end up as defendants rather than plaintiffs. Thus, instead of forum law, the consumer advocates in the American Law Institute prefer that the courts apply the law of the consumer's domicile to resolve conflicts, at least to the extent that the litigation implicates consumer protection laws at the domicile. ${ }^{64}$

Consider also noncompetition clauses in employment contracts. If an employer (1) intends to provide on-the-job training, (2) hopes to encourage the development of firm-specific (as opposed to employee-specific) human capital, or (3) needs to share valuable trade secrets with the employee, then the employer might include a noncompetition clause in the employment contract. The clause typically provides that the employee agrees not to work for a

of mobile individuals can be left to judicial discretion. The forum rule might provide both more, and more certain, benefits to plaintiffs than would a domicile rule.

63. Section 1-105(1) provides:

Except as provided hereafter in this section, when a transaction bears a reasonable relation to this state and also to another state or nation the parties may agree that the law either of this state or of such other state or nation shall govern their rights and duties. Failing such agreement this Act applies to transactions bearing an appropriate relation to this state.

U.C.C. $\$ 1-105(1)$ (1995).

64. Article 1 of the U.C.C. is currently being redrafted. NCCUSL approved a revision of section 1-105 at its 2001 Annual Meeting. The revision states that, where one of the parties to a U.C.C. transaction is a consumer, the choice of law by the courts "may not deprive the consumer of the protection of any rule of law governing a matter within the scope of this section, which both is protective of consumers and may not be varied by agreement, of the State or country: (A) in which the consumer principally resides ...." An exception applies when the consumer enters a contract for the sale of goods and takes delivery of those goods in a place other than the state of his residence. Draft Revision of the Uniform Commercial Code $\$ 1-301(d)$, at http://www.law.upenn.edu/bll/ulc/ucc1/ Ucc1_01 am.htm (approved by NCCUSL at its Annual Conference, August 10-17, 2001). 
competitor for a specified period of time after leaving the firm. States vary in the degree to which these clauses are enforceable. Many states will enforce these provisions so long as they are reasonable in geographic scope and duration, ${ }^{65}$ but a few states are reluctant to enforce these provisions against employees. ${ }^{66}$ When the firm is headquartered in a state that will enforce the clauses but the employee lives in or moves to a state where the clauses are unenforceable, litigation often proceeds in two states. The employee and the competitor file a declaratory judgment action in the employee's state, and the employer files a breach of contract action in the state where its headquarters are located. ${ }^{67}$ Each prefers that the law of its own domicile be applied to resolve the case, but because the courts are effectively applying a forum rule to the cases, the ultimate resolution of these cases turns on a race to judgment. ${ }^{68}$

I do not intend to take a position on the efficient resolution of these issues. Instead, I hope to point out that when a clear rule is proposed by a drafting body, the rule is a pretty good sign that only one of these competing interests was represented in that body. Moreover, that rule more likely reflects the single interest that is represented in the body than it does some concern for efficiently resolving the issue.

Schwartz and Scott further predict that drafting bodies will promulgate standards rather than rules when competing interest groups are actively involved in the negotiations. ${ }^{69}$ The fact that their interests are opposed indicates that each will work hard to eliminate the rules preferred by the other party. Any deviation from the status quo typically benefits one interest at the expense of the other, so that it will be opposed. The drafting body as a whole prefers to generate some product; otherwise, it will have failed in its mission. ${ }^{70}$ Eventually, then, the body compromises on a standard. The standard appears to represent a legal change, but, in reality, it also enables courts to continue with

65. See, e.g., Affiliated Paper Cos. v. Hughes, 667 F. Supp. 1436, 1445-50 (N.D. Ala. 1987); Reed, Roberts Assoc. v. Strauman, 353 N.E.2d 590, 593 (N.Y. 1976).

66. See, e.g., Enron Capital \& Trade Res. Corp. v. Pokalsky, 490 S.E.2d 136, 139 (Ga. Ct. App. 1997) (noting public policy concern with both covenants against disclosure and covenants against competition); Ronald J. Gilson, The Legal Infrastructure of High Technology Industrial Districts: Silicon Valley, Route 128, and Covenants Not to Compete, 74 N.Y.U. L. REv. 575, 607-08 (1999) (discussing California's refusal to enforce noncompetition clauses against employees).

67. See O'Hara, supra note 2, at 1566-67. Note that the employer could attempt to avoid double litigation with a choice-of-law provision, but the employee's state often refuses to enforce the provision because enforcement would violate a fundamental public policy of the employee's state. Id. The employee's state wants to preserve competitive markets for its consumers and ensure that its employees can use their talents to support themselves. Id.

68. See id.

69. Schwartz \& Scott, supra note 58 , at $648-50$.

70. Id. at 611 (noting that participants in private legislatures derive utility from having the body adopt a law-reform proposal, independently of the merits of the proposal in question); Stephan, supra note 2, at 961 ("[T] he people who negotiate international agreements, as well as the people who serve the institutions that promote these negotiations, have powerful incentives for achieving some kind of agreement regardless of substantive outcome. Association with a concluded agreement brings prestige, opportunities to offer interpretation, and invitations to participate in subsequent negotiations."). 
its preexisting choice-of-law decisions. The competing groups agree to support the standard precisely because it makes possible the preservation of the status quo ante. ${ }^{71}$ Once again, the form of the conflicts proposal can be expected to represent considerations other than efficiency.

\section{PROCEDURAL OR SUBSTANTIVE NEGOTIATIONS?}

One final point deserves attention from law and economics scholars. We need a careful understanding of where international choice-of-law resolutions can help resolve conflicts between states. The conflict of laws approach to international disagreement is attractive because it enables each individual state to preserve its bundle of substantive laws. Those laws differ for at least three possible reasons. First, the balance of interest group pressures varies from state to state, leading to differing legislative outcomes. ${ }^{72}$ When the balance of influence weighs in favor of one interest in a given state, efforts to harmonize substantive laws in a manner harmful to that interest will likely run into difficulties. By focusing on conflicts instead of substantive law, the dominant interest group can very often preserve at least some of the benefits of that law and therefore will invest less into opposing reform.

Second, state laws can differ because state environments differ. ${ }^{73}$ An urban state typically adopts very different laws about many issues, including gun ownership, traffic flow, and property use, than does a rural state. ${ }^{74}$ And it appears that culturally homogenous states would be more likely to have laws that help to define the cultural environment than would culturally diverse states. ${ }^{75}$ If one of the benefits of individual local governments is the ability to enable the laws to better fit individual environments, ${ }^{76}$ then the conflicts approach promises to help preserve legal diversity. ${ }^{77}$

Third, state laws differ because individual states differ in their willingness to invest

71. Schwartz \& Scott, supra note 59 , at 648-50.

72. See Jonathan R. Macey, Federal Deference to Local Regulators and the Economic Theory of Regulation: Toward a Public Choice Explanation of Federalism, 76 VA. L. REv. 265, 281 (1990).

73. Differing local laws can also help encourage and preserve diversity in social environments. See Note, A Niche for the Guarantee Clause, 94 HARv. L. REv. 681, 689 n.62 (1981).

74. Jonathan Macey makes a similar point about gun control. Macey, supra note 72, at 281 ("In general, states with largely urban populations tend to favor gun control while states with rural populations often prefer to provide citizens with broad rights to own and carry guns.").

75. Cf. S.I. Strong, Law and Religion in Israel and Iran: How the Integration of Secular and Spiritual Laws Affects Human Rights and the Potential for Violence, 19 Micr. J. INT'L L. 109, 213 n.538 (1997) ("Historically, incorporation of religious principles in law has only been successful in States that are highly homogenous and that are geographically and/or culturally isolated from the rest of the world.").

76. POSNER, supra note 2.

77. Difficulties arise when mobility of companies and individuals pressure states to enact uniform laws. Whether perceived as a race-to-the-top or a race-to-the-bottom, the strategic interaction of states can produce the same homogenization as multilateral harmonization efforts. For a discussion of race-to-the-top and race-to-the-bottom theories, see generally Henry N. Butler, Nineteenth-Century Jurisdictional Competition in the Granting of Corporate Privileges, 14 J. LeGAL STUD. 129 (1985); William W. Bratton \& Joseph A. McCahery, The New Economics of Jurisdictional Competition: Devolutionary Federalism in a Second-Best World, 86 GEo. L.J. 201 (1997). 
public resources into developing particular bodies of law. One state may find it advantageous to develop a particular field of law, and, as mentioned earlier, New York's commercial law and Delaware's corporate law provide examples within the United States. These bodies of law are valuable to the individual states because they attract business to the states; Delaware collects corporate filing fees, and New York attracts commercial business and litigation. If that body of law became available everywhere, because the law of every state was harmonized to look like their laws, then New York and Delaware lose their advantage. ${ }^{78}$ However confident Delaware is in the value of its substantive rules, its political leaders might nevertheless resist harmonization. Its representatives likely would rest their opposition on different grounds, such as the need for individual states to provide laboratories that help to keep inferior laws from becoming cemented in the legal landscape. Regardless of the cause for differing laws, the conflicts approach, where possible, may provide better, or at least less costly, solutions to states.

Unfortunately, the conflict of laws approach to resolving states' differences has real limits. To be effective, the states must acknowledge that the substantive laws of other countries deserve respect. This enlightened view is unlikely when the states find themselves in a zero-sum game with respect to the reach of their laws. Because Guzman uses patent and environmental law as examples in his article, ${ }^{79}$ I will focus on them here. Neither area of law has ever, to my knowledge, been the subject of choice-of-law discussions among states. I believe no such discussion has taken place because an agreement on choice of law is fundamentally unhelpful to the nations involved.

Disagreements among nations in these two areas essentially involve a question of which nations must pay for improvements in aggregate welfare. Patent protections provide incentives for innovation, but those incentives come at a cost to consumers who must pay higher prices for innovative goods. If country $A$ attempts, on its own, to provide incentives for innovation, then its consumers must pay more than if country $A$ is able to enlist the support of countries $B$ and $C$. Because $B$ 's and $C$ 's consumers enjoy the innovation, country $A$ takes the position that it is appropriate for them to share the burdens. $B$ and $C$ resist these efforts, arguing that because the lion's share of innovators are located in $A,{ }^{80} A$ benefits from the innovation far more than any other country. As a result, $B$ and $C$ claim it is appropriate for $A$ 's citizens to pay for the innovation. ${ }^{81} A, B$, and $C$ disagree about the substance of the laws in $B$ and $C$, and their disagreement cannot be alleviated in any meaningful way with choice of law.

78. Cf. Macey, supra note 72 , at 279 (offering a similar argument as partial explanation for why Congress has refrained from federalizing corporate law).

79. Guzman, supra note 1, at 933-34, 938.

80. After all, $A$ must have experienced relatively powerful interest group support in favor of intellectual property protection for it to have been the leader in law reform.

81. See Adriana Lieders, A New Chapter in Brazil's Oil Industry: Opening the Market While Protecting the Environment, 13 GEo. INT'L ENVTL. L. REv. 781, 797 (2001) (noting belief in developing countries that intellectual property rights merely preserve relative power of wealthy countries). 
A similar difficulty seems to arise with environmental laws. Country $A$ 's citizens want clean air and water, but trying to clean the world's resources unilaterally can be quite expensive. $A$ attempts to get $B$ and $C$ to make efforts in their countries, arguing that it is unfair that $B$ 's and $C$ 's citizens are free riding off of $A$ 's efforts. $B$ and $C$ argue that because $A$ is so much wealthier, $A$ should bear the expenses. ${ }^{82}$ Here, too, a choice-of-law rule would not begin to solve the problem. In each of these examples, $A$, the country with regulation (whether patent law or environmental law) is paying for a public good enjoyed by the nonregulating states, $B$ and $C$. A choice-of-law agreement would not satisfy $A$ because only a change in the substantive laws of $B$ and $C$ will redistribute the costs of providing clean air or technological innovations effectively. Countries therefore negotiate only at the level of substantive law.

I cannot say that I understand the necessary and sufficient conditions for choice-of-law negotiations to be attractive to states. I merely point out that we should think more about when conflicts law can help increase aggregate welfare and when only negotiations on substantive law will satisfy the demands of individual states. Guzman's talents seem particularly well-suited for the task.

\section{CONCLUSION}

Andrew Guzman has provided a very good, thought-provoking, original analysis of a very difficult and old problem. These comments are modest in their purpose-intended only to make all of us think harder about what efficient choice of law is and what we can realistically expect about the extent to which countries can and will enhance global welfare with choice of law. If successful, they will push Andrew Guzman further in his analysis. But that analysis, at its core, is both correct and potentially powerful. A new, impressive analytic force has come to the conflict of laws. I can only hope, enthusiastically, that he remains interested in the topic.

82. See William L. Andreen, Environmental Law and International Assistance: The Challenge of Strengthening Environmental Law in the Developing World, 25 CoLum. J. ENVTL. L. 17, 18-20 (2000) (developing countries view environmental law as a luxury only wealthy nations can afford). 